\title{
Hurghada coral diseases; are they due to the impacts of global warming or mass tourism?
}

Hany, A. Abdel-Salam ${ }^{\text {; }}$ Abdel-Hamid, A. M Ali ${ }^{2}$ and Amin, R. M. Ismail ${ }^{1}$

1- Department of Zoology, Faculty of Science, Benha University, Egypt.

2- National Institute of Oceanography and Fisheries, Suez branch, Egypt. Corresponding Author: Tel.: + 20123478716; E-mail: hanysalam100@hotmail.com

\section{ABSTRACT}

This study is trying to assess the types and frequencies of occurrence of coral diseases. Are these diseases due to the impacts of global warming or tourism on coral reefs along the Red Sea coast off Hurghada? Results indicated that there is a high disease prevalence (46\%) with the presence of four coral diseases/ syndromes; White Syndrome (21.6\%), Bleaching (16.2 \%), Black Band Disease (8.2\%) and overgrowth of sponge were near the sampling transects. Data of the Coral Reef Watch about the Sea Surface Temperature (SST) anomaly produced by National Oceanographic and Atmospheric Administration (NOAA) indicated that there was $1^{\circ} \mathrm{C}$ increase in SST in 2009 and $1.5^{\circ} \mathrm{C}$ increase in 2010 in the northern Red Sea region. The increased prevalence of coral diseases in the Red Sea coast off Hurghada might be attributed to sea surface temperature (SST) anomaly due to global warming. It might be also due to activities associated with tourism such as exaggerated coastal development through construction of hotels and increased sewage run off and unregulated recreational activities such as SCUBA diving, snorkeling, and reef walking. Coral reefs must be considered and incorporated into management plans. To conserve these valuable marine resources, we have to adopt the sustainability concept of ecotourism instead of mass and random tourism activities.

\section{INTRODUCTION}

It is a well-known fact that the sea covers three-quarters of the earth. If a third dimension is added-the sea-bed, with its canyons and slopes-the sea comprises an even greater proportion of the surface of the earth (Gray and Elliott, 2009). The Red Sea is one of the most important repositories of marine biodiversity in the world. It has an extraordinary range of biological diversity and endemism. The Red Sea is the habitat of over 1,000 invertebrate species, more than 1200 species of fishes, and 200 soft and hard corals. It is the world's northernmost tropical sea (Lieske and Myers, 2004).

Coral reefs are among the most biologically diverse and economically important ecosystems on the planet. They provide vital services to human societies and industries through fisheries, and coastal protection. New biochemical compounds that might be found and can be used as sources of new drugs for treatment of many diseases such as cancer and AIDS (Moberg and Folke, 1999).

Although Red Sea reefs are cited among the most diverse ecosystems in the world (Loya, 1972), Red Sea corals were not well studied (Rinkevich, 2005).

Since the first report of coral disease by Antonius (1973), the rate of discovery of new diseases has increased dramatically, and about 30 coral diseases were recorded (Weil, 2003). Coral diseases outbreaks not only result in coral loss, but they also 
cause significant changes in community structure, species diversity and reefassociated organisms (Beeden et al., 2008).

Although coral disease is emerging as a serious cause of coral reef deterioration in many reefs around the world, at present very little is known about the ecology or pathology of coral diseases in Red Sea reefs, in general (Antonius and Riegl, 1997).

Increases in temperatures around the globe and changes in weather patterns, particularly El Niño Southern Oscillations, are dramatically influencing the health and composition of coral reefs through outbreaks of significant bleaching events. In 1998, the most widespread bleaching event on record swept across the globe, and destroyed $16 \%$ of the world's coral reefs (Mydlarz et al., 2010).

Forecast sea surface temperature (SST) models predict that the frequency and severity of warm temperature anomalies will increase with climate change. These anomalies and the general warming of the ocean could have several effects on coral diseases prevalence (Sheppard and Rioja-Nieto, 2005).

Tourism development plays a critical role in coral reefs destruction. Coral reefs are vulnerable to the effects of tourism and unregulated recreational activities. Random diving and water sports have already caused big damage to coral reefs in Hurghada. In addition, dredging and infilling for tourism development and coastal engineering projects have drastically altered wide areas of near shore coastal habitats. Unfortunately, much of the development has been conducted without the benefit of strict planning/zoning control and, as a result, an abundance of hotels has emerged with little or no regard for the environment (Wahab, 1997).

The present study aims to assess the impacts of global warming and tourism on the types and frequencies of occurrence of coral diseases/ syndromes in Coral reefs along the Red Sea coast off Hurghada, Egypt.

\section{MATERIALS AND METHODS}

\section{A) Study area:}

Data were collected from the crescent reef situated off the marine biological station, at approximately $6 \mathrm{Km}$ north of Hurghada city along the Red Sea coast, Egypt Fig. 1. This reef is located $300 \mathrm{~m}$ offshore and lies at $27^{\circ} 17^{\circ} \mathrm{N}$ and $33^{\circ}$ $46^{\circ}$ E. reef. It is oblique to the shore line and has crescent shape. It is approximately $470 \mathrm{~m}$ long and $70 \mathrm{~m}$ wide.

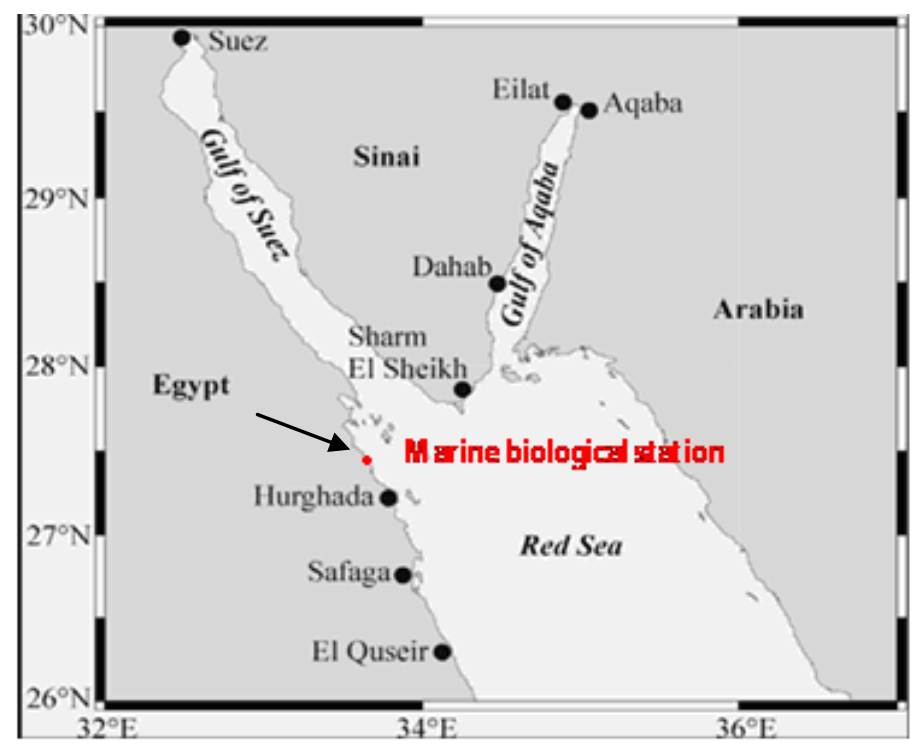

Fig.1: Map showing the study area 


\section{B) Survey Method:}

Surveys were conducted using line transect method (Loya, 1978). In this method, transect lines (20 meter) were employed to act as a guide along which color photographs were taken by underwater digital camera (Sea Life ECOShot/ SL321) every half meter continuously. Three replicate transects were surveyed at 3-5 m depth. The 20-m transect lines were haphazardly laid just above the reef surface in a direction that is parallel to the long axis of the reef. The entire survey was carried out using SCUBA diving technique. Hard corals were identified to species level according to Wallace (1999) and Veron (2000).

\section{C) Disease Identification:}

Identification of diseased corals in the field was based on the appearance of lesions, and some variables as the color of the affected tissue and/or the pattern of tissue loss. Photographs of diseased corals were taken and identified using Underwater Cards for Assessing Coral Health in Indo-Pacific Reefs by (Beeden et al. 2008).

\section{D) Data Analysis:}

The growth form, total number of colonies, number of healthy colonies, number of diseased colonies and disease type were determined for each coral colony. Data were expressed as prevalence which is the proportion or percentage of diseased colonies. Prevalence of a certain disease was calculated as follows:

(Number of diseased colonies / total number of coral colonies) x 100

All numerical data were statistically analyzed and expressed as mean \pm SE. The Student's t-test was applied to evaluate the significance between means of each two sets of data (Snedecor, 1971).

\section{E) Using Remote Sensing to Explore the Climate Warming:}

Using data of Coral Reef Watch satellite (SST) Sea Surface Temperature anomaly produced by (NOAA) National Oceanographic and Atmospheric Administration in 2007, 2008, 2009, and 2010, http://coralreefwatch.noaa.gov.

\section{RESULTS}

Field surveys for coral diseases/syndromes in the studied reef, revealed that about $46 \%$ overall diseases prevalence (Fig. 2). Signs corresponding to three coral diseases were detected in the sampling transects; white syndrome (WS), Black Band Disease (BBD), and Bleaching (BL). Overgrowth of sponges were detected near to the sampling transects.

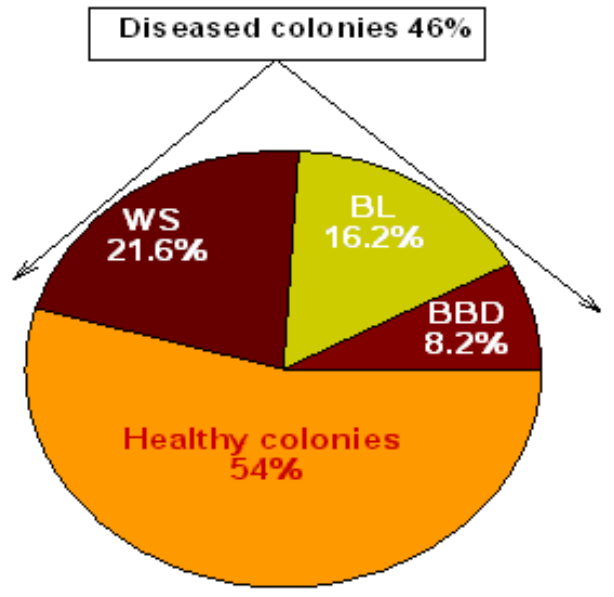

Fig. 2: The percentages of healthy \& diseased colonies and the percentages of prevalence of each coral disease. 
Figs. (3\&4) show that the massive coral colonies are more susceptible to diseases than the branched coral colonies.

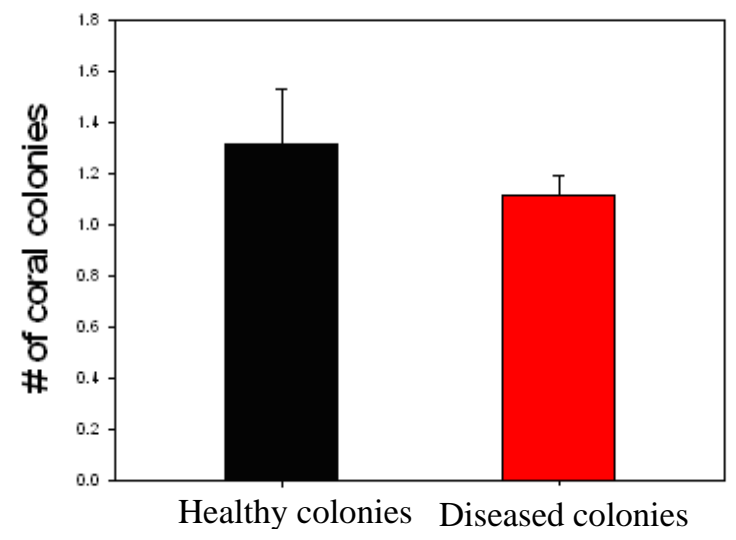

Fig. 3: The mean and standard errors of healthy and diseased coral colonies

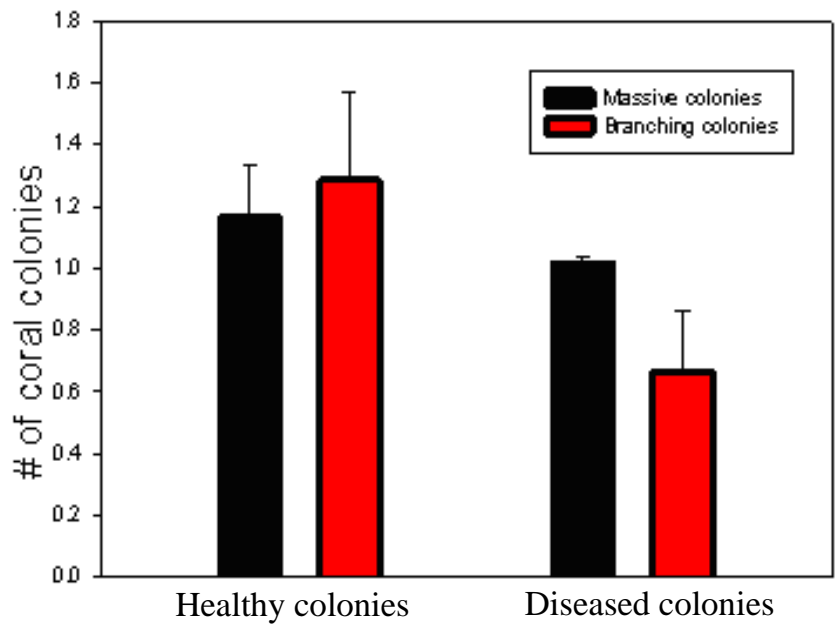

Fig. 4: The mean and standard errors of healthy and diseased colonies of both massive and branching corals.

Prevalence of coral diseases is shown in Fig. (2). White Syndrome (WS) has the highest prevalence $21.6 \%$, Bleaching (BL) has $16.2 \%$ prevalence, while Black Band Disease (BBD) has $8.2 \%$. The underwater photographs of each coral disease are shown in Fig. 5, Tables (1\&2).

Table (1): Description of coral diseases/ syndromes found on corals in the Red Sea coast off Hurghada.

\begin{tabular}{|c|l|}
\hline Coral disease/ syndrome & \multicolumn{1}{c|}{ Description } \\
\hline $\begin{array}{c}\text { Bleaching (BL) } \\
\text { Figs. 5A, 5B \& 5C }\end{array}$ & $\begin{array}{l}\text { It is the whitening of coral colonies due to temporary or permenant loss of the endosymbiotic } \\
\text { algae (zooxanthellae). It may be partial or complete (whole colony). }\end{array}$ \\
\hline $\begin{array}{c}\text { Overgrowth of sponge } \\
\text { Fig. 5D }\end{array}$ & $\begin{array}{l}\text { Cliona sponges progressively kill and overgrow coral skeleton. A zone of white exposed } \\
\text { skeleton between sponge and coral may be evident. }\end{array}$ \\
\hline $\begin{array}{c}\text { Black Band Disease (BBD) } \\
\text { Figs. 5E \& 5F }\end{array}$ & $\begin{array}{l}\text { It is characterized by a blackish concentric or crescent-shaped band, 1 to 30 mm wide and up to } \\
\text { skeleton. }\end{array}$ \\
\hline $\begin{array}{c}\text { White syndrome (WS) } \\
\text { Figs. 5G \& 5H }\end{array}$ & $\begin{array}{l}\text { Presence of narrow zone of a recently exposed white skeleton and a relatively regular } \\
\text { appearance of the tissue in front of the skeleton. Tissue death appears to begin in the center of } \\
\text { the colony and spread toward the margin. Older exposed skeleton is algae-colonized. }\end{array}$ \\
\hline
\end{tabular}


Hurghada coral diseases; are they due to the impacts of global warming or mass tourism? 37

Table (2): Coral species affected by diseases/ syndromes in the Red Sea coast off Hurghada.

\begin{tabular}{|c|c|c|c|c|c|}
\hline Species & BBD & WS & $\overline{\text { Bl }}$ & Overgrowth of sponge & \#of diseases \\
\hline Platygyra daedalea & $\mathrm{X}$ & $\mathrm{x}$ & $\mathrm{x}$ & --- & 3 \\
\hline Diploastrea heliopora & --- & ---- & $\mathrm{x}$ & --- & 1 \\
\hline Fungia fungites & ---- & ---- & $\mathrm{X}$ & --- & 1 \\
\hline Goniastrea retiformis & --- & $\mathrm{X}$ & $\mathrm{X}$ & --- & 2 \\
\hline Acropora clathrata & ---- & $\mathrm{X}$ & ---- & ---- & 1 \\
\hline Favia favus & ---- & --- & $\mathrm{X}$ & ---- & 1 \\
\hline Porites solida & $\mathrm{x}$ & --- & --- & $\mathrm{x}$ & 2 \\
\hline Goniastrea pectinata & $\mathrm{X}$ & --- & --- & --- & 1 \\
\hline Acropora granulosa & --- & --- & $\mathrm{X}$ & ---- & 1 \\
\hline
\end{tabular}

$\mathrm{BBD}=$ Black Band Disease

WS $=$ White Syndrome

$\mathrm{BL}=$ Bleaching

\section{Remote Sensing data:}

Data of Sea Surface Temperature (SST) anomaly in the Red Sea reveal and that there was no Sea Surface Temperature anomaly in 2007 and 2008 (Figs. 6 A \& 6 B) while in 2009 there was $1{ }^{\circ} \mathrm{C}$ increase and in 2010 there is $1.5^{\circ} \mathrm{C}$ increase (Figs. $6 \mathrm{C} \&$ 6D). Fig. 7 shows that there was bleaching watch in 2008 in July, August, September, and October and in 2009 in June, July, August, September, October, and November.

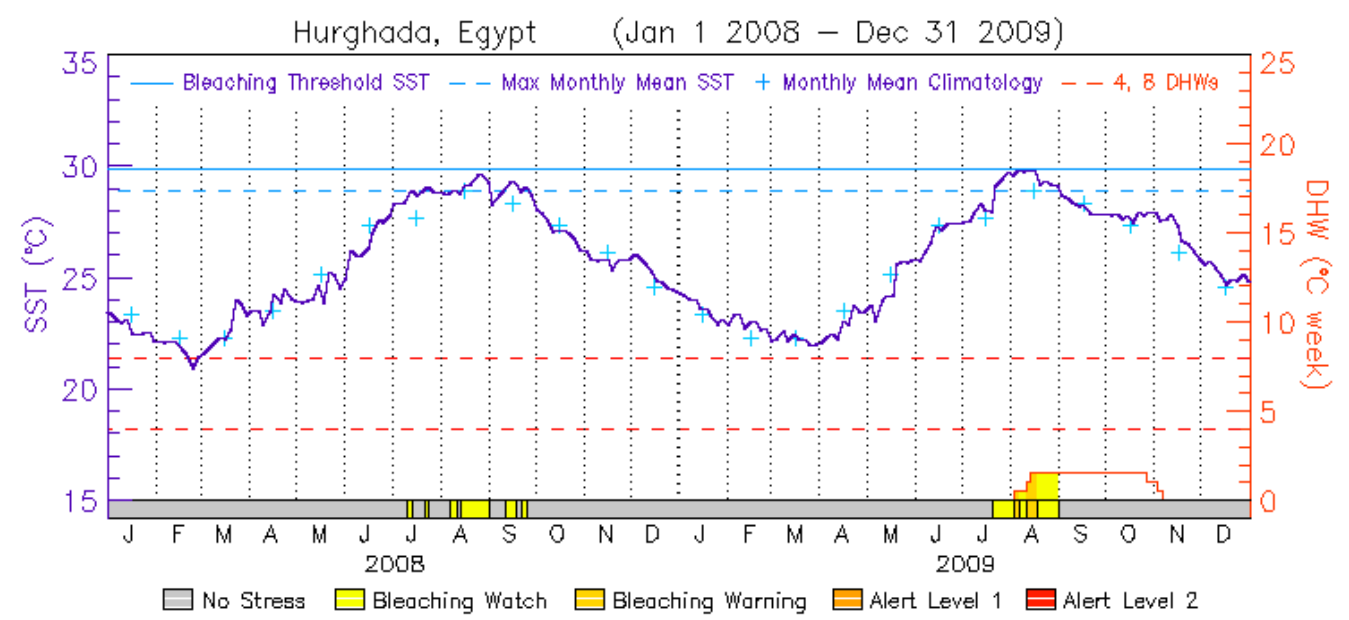

Fig. 7: Chart showing max monthly mean SST $\left({ }^{\circ} \mathrm{C}\right)$, bleaching threshold SST and the monthly mean climatology from 2008 to 2009.

\section{DISCUSSION}

There is mounting evidence that the emergence of new coral diseases is increasing, and the geographical distribution of diseases is extending. Information 
regarding coral diseases in the Indo-Pacific region is limited and little quantitative work has been accomplished (Harvell et al., 2004).

The present study verified the presence of four coral diseases in Hurghada coral reefs: Bleaching (BL), White Syndrome (WS), Black Band Disease (BBD), and overgrowth of sponges. The occurrence of white syndrome, black band disease, and Bleaching in the northern Red Sea was observed by (Antonius, 1988). Also, Antonius and Riegl (1998) reported white syndrome on the reefs of the Sinai Peninsula. Al-Moghrabi (2001) reported outbreaks of black band disease in the northern Red Sea. Rosenberg and Ben-Haim (2002) and Loya (2004) reported Bleaching and black band disease in Eilat reefs, Red Sea.

Coral diseases found in this study are widely distributed both in the Indo-Pacific and the Caribbean. Black band disease affects corals worldwide. It is common in shallow water, and it is now seen everywhere in the Caribbean (Bruckner et al., 1997). White Syndrome and Black Band Diseases were recorded in the Great Barrier Reef, Australia (Willis et al., 2004); in the Philippine reefs (Raymondo et al., 2005); in Zanzibar and Kenya, East Africa (Weil, 2006). Haapkyla et al. (2007) reported the presence of Syndrome White in Indonesia. Beeden et al. (2008) reported the occurrence of white syndrome, black band disease, Bleaching, and Overgrowth of sponges in the Great Barrier Reef, Australia.

The present results indicated high disease prevalence of $46 \%$ of coral reef community in the investigated site. Compared to other regions in the world, levels of diseases in the Red Sea coast of Hurghada are high. $11 \%$ in St. Lucia, West Indies (Nugues, 2002), 8.3\% in the Philippines (Raymundo et al., 2005), 6.21-13.58\% in the Solitary Islands, Australia (Dalton and Smith, 2006), 0.57\% in Indonesia (Haapkyla et al., 2007), and 8.9\% in Southeastern India (Thinesh et al., 2009). The present results indicated that the massive coral colonies are more susceptible to diseases than the branched coral colonies. Same observation was reported in Puerto Rico by (Bruckner and Hill , 2009). Massive coral colonies are more vulnerable to stress and disturbance as they have slow growth rate (Gladfelter et al., 1987).

Hoegh-Guldberg et al. (2007) reported that elevated sea surface temperature associated with the global climate change is the main cause of coral bleaching. The general rise in the atmospheric $\mathrm{CO}_{2}$ and the increase in UV radiation are suspected to be the most important factors of the global warming.

Data of Sea Surface Temperature (SST) anomaly in the Red Sea reveal that there was $1{ }^{\circ} \mathrm{C}$ increase in 2009 and $1.5^{\circ} \mathrm{C}$ increase in 2010 . These results reflect the expected general warming trends of the Oceans. It is predicted that there will be 1.4$5.8^{\circ} \mathrm{C}$ increase in Earth surface temperatures by 2100 (IPCC, 2001). As temperatures continue to increase, events such as El Niño Southern Oscillation (ENSO) could become more frequent and climate change may now be the single greatest threat to coral reefs worldwide (West and Salm, 2003). Selig et al. (2006) reported that rising ocean temperatures could exacerbate the effects of coral diseases on coral reefs ecosystems.

The increase in the concentration of atmospheric $\mathrm{CO}_{2}$ poses a threat to coral reefs by causing changes in global seawater chemistry; decreasing the concentration of carbonate ions and the water acidity increases. Thus, leading to decreases in coral calcification rates, growth rates and structural strength. As more $\mathrm{CO}_{2}$ enters the Ocean, the water acidity increases (Grimsditch and Salm, 2006). Mitchell (2009) stated that once the Ocean $\mathrm{pH}$ reaches a certain point, the water become acidic enough to corrode the healthy reefs. 
Hoegh-Guldberg et al. (2007) stated that increases in the temperature of tropical and subtropical waters over the past 50 years have already pushed reef-building corals close to their thermal limits; as the sea surface temperatures exceed the normal summer temperatures by $1^{\circ} \mathrm{C}$ to $2^{\circ} \mathrm{C}$, the symbiotic relationship between zooxanthellae and corals will be disturbed. When water temperature increases, the algal symbionts photosynthesise more quickly. This increases the amount of oxygen they produce which can increase to toxic levels within the corals' tissues. To survive, corals expel most, if not all, of the algae from their tissues, thereby losing their source of energy. Corals appear white or 'bleached' because when the pigmented algae are gone, the white calcareous skeleton becomes visible through the transparent coral tissues.

Mitchell (2009) stated that global warming holds out the potential of increasing the sea level. As land-based ice sheets in Antarctica melt in the warmer climate, extra water will pour into the global ocean basin. These higher sea levels will put many of the world's remaining healthy reefs so far under water that the algae (zooxanthellae) won't be able to catch enough of the sun's rays to photosynthesize.

Of all tourist activities, diving has received the greatest attention in recent years. In the early1990s very little research had been done on the environmental impacts of diving. Studies have concluded that high levels of diving activity at a single site can cause detectable changes to the coral communities, and eventually, a change to the aesthetics of the reef if diving intensity is high enough (Hawkins and Roberts 1992). The damage occurs primarily to fragile branching corals, and site selection to avoid more sensitive sites should be considered when establishing locations where large numbers of divers will visit (Rouphael and Inglis, 1997). The number of divers per site at which damage becomes apparent was found to be around 5,000 divers per site per year (the carrying capacity). In the Red Sea up to 50,000 dives per site per year have been recorded and cause visible damage to coral communities, and growth in diver numbers was expected to continue (Hawkins and Roberts 1997). There are about 600,000 dives per year taking place in Hurghada (Wearing \& Neil, 1999).

Snorkeling has been less studied than scuba diving, but because most tourists stay on the surface of the water when snorkeling, they are less likely to impact on the reef. However, Allison (1996) reported that most damage in the Maldives occurred when snorkelers kicked or stood on coral colonies.

Excessive sedimentation arising from coastal development and construction activities mainly for tourism development such as: construction of hotels, increased sewage run- off. Such activities decrease water quality, particularly due to eutrophication and sedimentation (Bruno et al., 2003). An example of negative tourism activity is sewage oxidation pond in one of the hotels on Hurghada coast. These oxidation ponds are characterized by high nutrients water. They are located near the sea and the high nutrient water reaches the sea either by flooding or seepage. Most coral reefs grow in water that is naturally low in nutrients. When nutrients are added, macroalgae may grow much faster and shade out the slow-growing corals. Such accelerated algal growth due to nutrient input is called eutrophication (Castro and Huber, 2002).

Frias-Lopez et al. (2002) have reported the presence of pathogenic bacteria as: Lactobacilli and Streptococci in a black band mat, suggesting that human sewage and terrestrial run-off may contribute to the development of black band disease. Eutrophication causes enhanced disease progression. Recent evidence suggests a synergistic relationship between elevated nutrients and disease. High- nutrient levels 
(nitrogen and phosphorus) were associated with accelerated tissue loss in black band affected corals (Voss and Richardson, 2006).

Siltation offers yet another challenge to host disease resistance. The impacts of sedimentation on near shore communities are visible and well documented; corals inhabiting silted reefs are often observed to possess large patches of dead, exposed skeleton. Dredging near coral reefs and accelerated runoff of eroded soils increase turbidity, thereby cutting down light available for photosynthesis, as well as increasing sediment load on corals. Sediments that settle on coral colonies or that cause high turbidity, while suspended in the water column have sub-lethal and lethal effects (Rogers, 1990).

The sustainable development in Hurghada, the capital of the Red Sea Governorate, has had disastrous results, with $80 \%$ of the live coral along that portion of the coastline effectively destroyed (Wearing \& Neil, 1999).

The environment is the main base for the natural and cultural resources for attracting tourists worldwide (Bonn et al., 2005). The tourism industry is reliant on a healthy attractive environment for its sales. A research by Shafer and Inglis (2000) has reported that the most significant factors influencing the enjoyment of day visitors to the GBR are staff interactions, and the quality of the corals and fish. Thus, there is strong motivation to protect and conserve reefs that are the subject of tourism interest.

One of the tools of enhancing coral reef resilience is the sustainability concepts of ecotourism. The World Conservation Union (1996) explains that ecotourism as "environmentally responsible travel and visitation to relatively undisturbed natural areas, in order to enjoy, appreciate nature; it promotes conservation, has low negative visitor impact, and provides beneficially active socioeconomic involvement of local populations." This could be called, as a concept, Ecotourism Resources Management, which is a component of the field of sustainable tourism development (Wood \& Halpenny, 2001). Ecotourism refers to low-impact, nature-based tourism that causes less damaging effects on a destination's environmental, social, and economic than conventional mass tourism, and it can be used as an effective sustainable development tool (Horochowski \& Moisey, 2001)

Marine Protected Areas (MPAs) are the most widespread management strategy employed to enhance coastal ecosystem resilience and protect coral reefs. Although an MPA designation cannot directly protect coral reefs from bleaching and other diseases, it can be used to improve coral reef resilience by protecting coral reefs from other anthropogenic disturbances. For example, anthropogenic impacts such as: increased nutrient loads, pollution, diver and boat damage, sedimentation and overfishing can be reduced. The reduction of these direct stresses contributes to resilience larval sources that are essential for coral reefs recovery (Grimsditch and Salm, 2006).

In conclusion, the increased prevalence of coral diseases in the Red Sea coast off Hurghada might be attributed to sea surface temperature SST anomaly due to global warming. It might be also due to activities associated with tourism such as: exaggerated coastal development through construction of hotels, increased sewage run off and unregulated recreational activities such as: SCUBA diving, snorkeling, and reef walking. Coral reefs must be considered and incorporated into management plans. To conserve these invaluable marine resources: we have to adopt the sustainability concept of ecotourism instead of mass and random tourism activities. 


\section{REFERENCES}

Allison, W. R. (1996). Snorkeler damage to reef corals in the Maldive Islands. Coral Reefs, 15: 215-218.

Al-Moghrabi, S. M. (2001). Unusual black band disease (BBD) outbreak in the northern tip of the Gulf of Aqaba (Jordan). Coral Reefs, 19:330-331.

Antonius, A. (1973). New observations on coral destruction in reefs. Abs. Assoc. Isl. Mar. Lab. Caribb., 10:3

Antonius, A. (1988). Distribution and dynamics of coral diseases in the eastern Red Sea. Proc. $6^{\text {th }}$ Inter. Coral Reef Sym., 2: 293-298.

Antonius, A. and Riegl, B. (1997). A possible link between coral diseases and a corallivorous snail (Drupella cornus) outbreak in the Red Sea. Atoll Res. Bull., 447:1-9.

Antonius, A. and Riegl, B. (1998). Coral diseases and Drupella cornus invasion in the Red Sea. Coral Reefs, 17:48.

Beeden, R.; Willis, B.L.; Raymundo, L. J.; Page, C. A. and Weil, E. (2008). Underwater cards for assessing coral health on Indo-pacific reefs. http://www. Gefcoral.org. [Accessed 01/2010]

Bonn, M. A.; Joseph, S. and Dai, M. (2005). An empirical analysis of ecogeneralists visiting Florida: 1998-2003. Tourism Analysis, 10: 165- 185.

Bruckner, A.W.; Bruckner, R.J. and E Williams, J.R. (1997). Spread of a black-band disease epizootic through the coral reef system in St. Ann's Bay, Jamaica. Bull. Mar. Sci., 61:918-928

Bruckner, A.W. and Hill, R. L. (2009). Ten years of change to coral communities off Mona and Desecheo Islands, Puerto Rico, from disease and bleaching. Dis. Aquat. Org. 87: 19-31.

Bruno, J. F.; Petes, L.; Harvell, C. D. and Hettinger, A. (2003). Nutrient enrichment can increase the severity of two Caribbean coral diseases. Ecol. Let., 6:1,0561,061 .

Castro, P. and Huber, M. (2002). Coral reefs. In Marine Biology. $3^{\text {rd }}$ ed. Boston: McGraw-Hill.14:297- 320.

Dalton, S. J. and Smith, D. A. (2006). Coral disease dynamics at a subtropical location, Solitary Islands Marine Park, eastern Australia. Coral Reefs, 25:37-45.

Frias-Lopez, J.; Zerkle, A. L.; Bonheyo, G. T. and Fouke, B.W. (2002). Partitioning of bacterial communities between seawater and healthy black band diseased and dead coral surfaces. Appl. Environ. Microbiol. 68: 2214-2228.

Gladfelter, W. B.; Monahan, R. K. and Gladfelter, W. B. (1978). Growth rates of five reef-building corals in the northeastern Caribbean. Bull. Mar. Sci., 28:728-732.

Gray, J.S. and Elliott, M. (2009): Ecology of marine sediments: From science to management. $2^{\text {nd }}$ Ed., Oxford University Press, New York.

Grimsditch, G. D. and Salm, R. V. (2006). Coral Reef Resilience and Resistance to Bleaching. IUCN. Gland, Switzerland, 52pp.

Haapkyla, J.; Seymour, A. S.; Trebilco, J. and Smith, D. (2007). Coral disease prevalence and coral health in the Wakatobi Marine Park, south-east Sulawesi, Indonesia. J. Mar. Biol. Assoc. UK., 87: 403-414.

Harvell, C. D.; Aronson, R.; Baron, N.; Connell, J.; Dobson, A.; Ellner, S.; Gerber, L.; Kim, K.; Kuris, A.; McCallum, H.; Lafferty, K.; McKay, B.; Porter, J.; Pascual, M.; Smith, G.; Sutherland, K. and Ward, J. (2004). The rising tide of ocean diseases: Unsolved problems and research priorities. Frontiers in Ecology, 2(7):375-382. 
Hawkins, J. P. and Roberts, C. M. (1992). Effects of recreational SCUBA diving on fore-reef slope communities of coral reefs. Biol. Conserv. 62: 171-178.

Hawkins, J. P. and Roberts, C. M. (1997). Effects of recreational SCUBA diving on coral reefs. Trampling of reef flats communities. J. Appl. Ecol., 30: 25-30.

Hoegh-Guldberg, O.; Mumby, P.; Hooten, A. J.; Steneck, R. S.; Greenfield, P.; Gomez, E.; Harvell, C. D.; Sale, P. R.; Edwards, A. J.; Caldeira, K.; Knowlton, N.; Eakin, M.; Iglesias-Prietas, R.; Muthiga, N.; Bradbury, R.; Dubi, A. and Hatzeolus, M. (2007). The carbon crisis: Coral reefs under rapid climate change and ocean acidification. Science, 318:1737.

Horochowski, K. and Moisey, R. N. (2001). Sustainable tourism: The effect of local participation in Honduran ecotourism development. In McCool, S. F. \& Moisey, R.N. (Eds.), Tourism recreation and sustainability: Linking culture and the environment. UK: CABI Publishing, pp. 163-176.

Intergovernmental Panel on Climate Change (IPCC) (2001). Climate Change 2001: The Scientific Basis. Cambridge University Press. Cambridge (UK), 881 pp.

Kim, H.; Webster, P.J. and Curry, J. A. (2009). Impact of Shifting Patterns of Pacific Ocean Warming on North Atlantic Tropical Cyclones. Science, 325 (5936): 77- 80.

Lieske, E. and Myers, R.F. (2004). Coral Reef Guide Red Sea: The Definitive Guide to Over 1200 Species of Underwater Life. London, HarperCollins.

Loya, Y. (1972). Community structure and species diversity of hermatypic corals at Eilat, Red Sea. Mar. Biol., 13:100-123.

Loya, Y. (1978). Plotless and transect methods. In: Monographs on Oceanic Methodology. Coral Reefs: Research Methods. Stoddart, D.R. and Johannes, R.E. (Eds.). UNESCO Press, 5: 197-218.

Loya, Y. (2004). The Coral Reefs of Eilat - Past,Present and Future: Three Decades of Coral Community Structure Studies. In Coral health and disease (ed. E. Rosenberg and Y. Loya). Berlin: Springer-Verlag.

Mitchell, A. (2009). The last best place on Earth Great Barrier Reef. In Sea sick: The global ocean in crisis, pp. 21-40.

Moberg, F. and Folke, C. (1999). Ecological goods and services of coral reef ecosystems. Ecol. Econ., 29(2): 215.

Mydlarz, L.D.; McGinty, E.S. and Harvell, C.D. (2010). What are the physiological and immunological responses of coral to climate warming and disease? J. Exp. Biol., 213:934-945.

National Oceanographic and Atmospheric Administration (NOAA) (2010). Coral reefs watch satellite monitoring. http://coralreefwatch. noaa.gov. [Accessed 02/2010].

Nugues, M. M. (2002). Impact of a coral disease outbreak on coral communities in St. Lucia: What and how much has been lost? Mar. Ecol. Prog. Ser. 229: 61-71.

Obura, D. (2005). Resilience and climate change: Lessons from coral reefs and bleaching in the Western Indian Ocean. Estuarine, Coastal and Shelf Science, 63: 353-372.

Raymundo, L.; Rosell, K. B.; Reboton, C. T. and Kaczmarsky, L. (2005). Coral diseases on Philippine reefs: genus Porites is a dominant host. Dis. Aqua. Org., 64: 181-191.

Rinkevich, B. (2005). What do we know about Eilat (Red Sea) reef degradation? A critical examination of the published literature. J. Exp. Mar. Biol. Ecol., 327:183-200.

Rogers, C. S. (1990). Responses of coral reefs and reef organisms to Sedimentation. Mar. Ecol. Prog. Ser., 62:185-202. 
Rosenberg, E. and Ben-Haim, Y. (2002). Microbial diseases of corals and global warming. Environ. Microbiol., 4(6): 318-326

Rouphael, B. A. and Inglis, G. J. (1997). Impacts of recreational scuba diving at sites with different reef topographies. Biol. Conserv. 82: 329-336.

Selig, E. R.; Harvell, C. D.; Burno, J. F.; Willis, B. L.; Page, C. A.; Sweatman, H. and Casey, K. (2006). Analyzing the Relationship between Ocean Temperature Anomalies and Coral Disease Outbreaks at Broad Spatial Scales. In: Climate Change and Coral Reefs, Phinney, J. (Ed.). AGU Press.

Shafer, C. S. and Inglis, G. J. (2000). Influence of social, biophysical, and managerial conditions on tourism experiences within the Great Barrier Reef World Heritage Area Environ. Manag., 26: 73-87.

Sheppard, C. R. C. and Rioja-Nieto, R. (2005). Sea surface temperature 1871- 2099 in 38 cells in the Caribbean region. Mar. Environ. Res., 60(3): 389-396.

Snedecor, G.W. (1971). Statistical methods, $14^{\text {th }}$ (Ed.) The lowa state collage press, Ames, Lowa, USA .

Thinesh, T.; Mathews, G. and Patterson Edward, J.K. (2009): Coral disease prevalence in Mandapam group of islands, Gulf of Mannar, Southeastern India. Indian J. Mar. Sci., 38(4): 444-450.

Veron, J. E. N. (2000). Corals of the world. Australian Institute of Marine Science. Townsville. (3): 477.

Voss, J. D. and Richardson, L. L. (2006). Coral diseases near Lee Stocking Island, Bahamas: Patterns and potential drivers. Dis. Aqua. Organ., 69:33-40.

Wahab, S. E. A. (1997). Tourism development in Egypt: Competitive strategies and implications. In Cooper, C. and Wanhill, S. (Eds.), Tourism development: Environmental and community issues. London: John Wiley \& Sons.

Wallace, C. C. (1999). Staghorn corals of the world: A revision of the coral genus Acropora. CSIRO publishing, Australia.

Wearing, S. and Neil, J. (1999). Ecotourism: Impacts, potentials and possibilities. Oxford, UK: Butterworth-Heinemann.

Weil, E. (2003). Coral reef diseases in the wider Caribbean: status and prognosis. In: Rosenberg, E. and Loya, Y. (Eds) Coral health and disease. Springer, Berlin Heidelberg New York.

Weil, E.; Smith, G. W. and Gil-Agudelo, D. L. (2006). Status and progress in coral reef disease research. Dis. Aqua. Org. 69:1-7.

West, J. M. and Salm, R. V. (2003).Resistance and resilience to coral bleaching: Implications for coral reef conservation and management. Conserv. Biol. 17: 956-967.

Willis, B. L.; Page, C. A. and Dinsdale, L. A. (2004). Coral disease on the Great Barrier Reef. In Coral health and disease (ed. E. Rosenberg and Y. Loya), pp. 69-104. Berlin: Springer-Verlag.

Wood, M. E. and Halpenny, E. A. (2001). Ecotourism certification and evaluation: Progress and prospects. In Font, X. \& Buckley, R. C. (Eds.), Tourism ecolabeling: Certification and promotion of sustainable management. UK: CABI Publishing. 

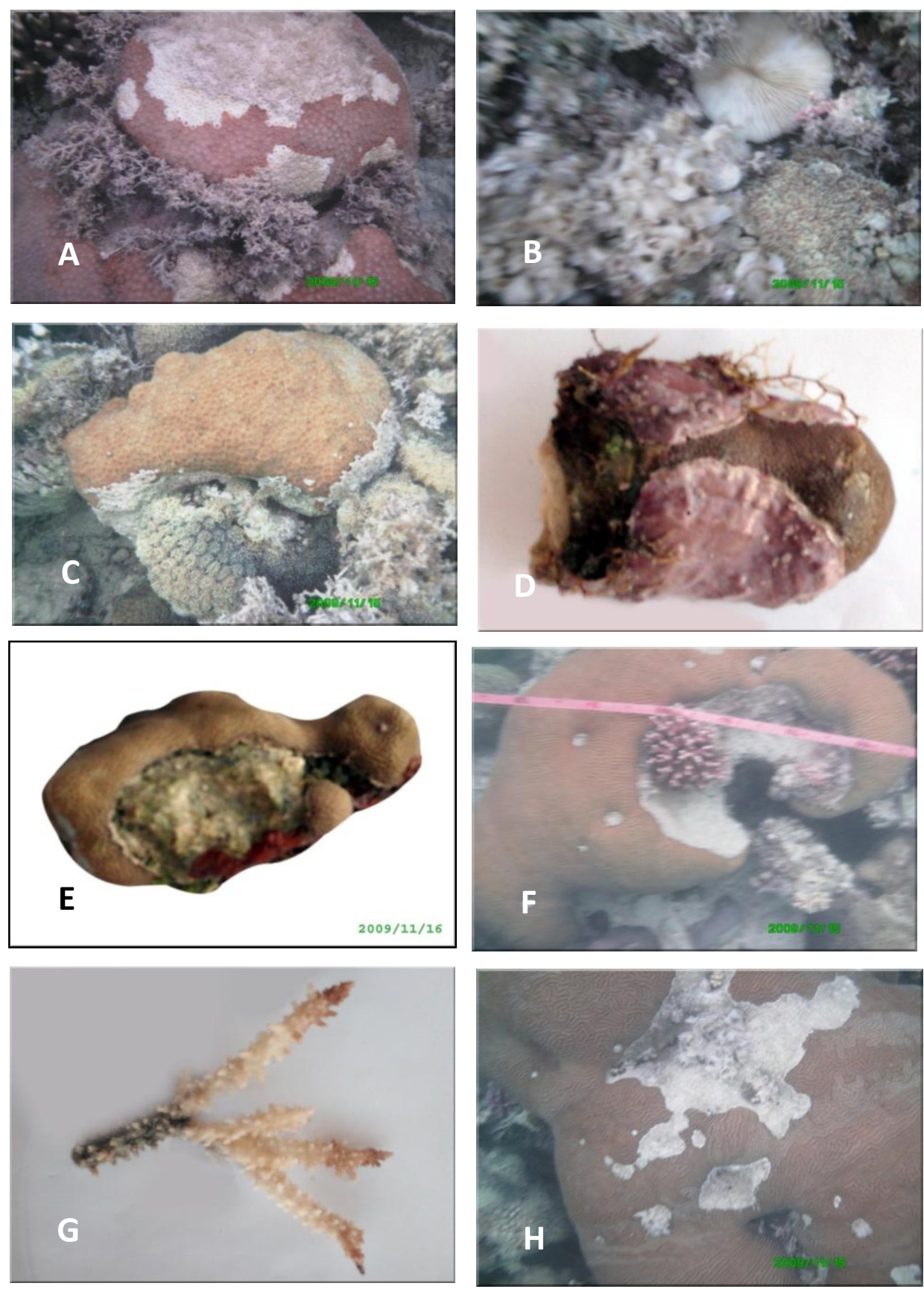

Fig. 5: Photographs of coral diseases/syndromes. (A) Bleached colony of Diploastrea heliopora, (B) Completely bleached Fungia fungites, (C) Bleached colony of Goniastrea retiformis, (D) Overgrowth of Cliona sponge, E)Black Band Disease (BBD) on Porites solida colony, (F) Platygyra daedalea colony showing Black Band Diseaese (BBD), (G) shows White Syndrome on Acropora clathrata, and (H) Platygyra daedalea colony showing White Syndrome. 


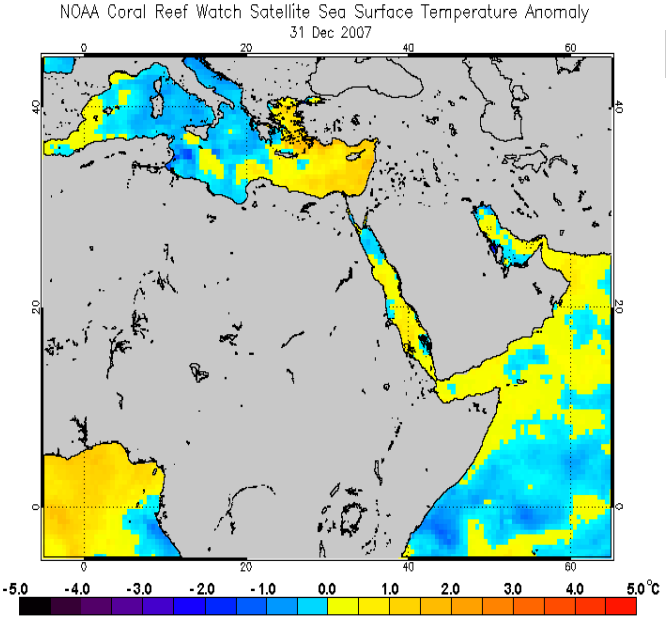

(A)

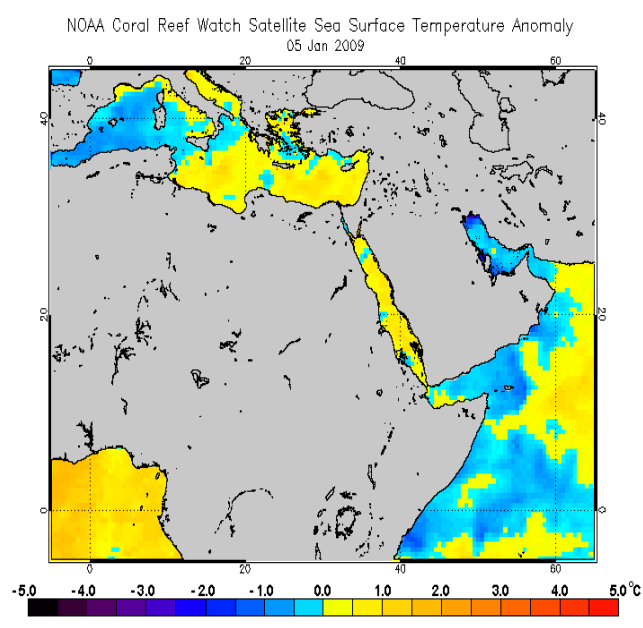

(C)

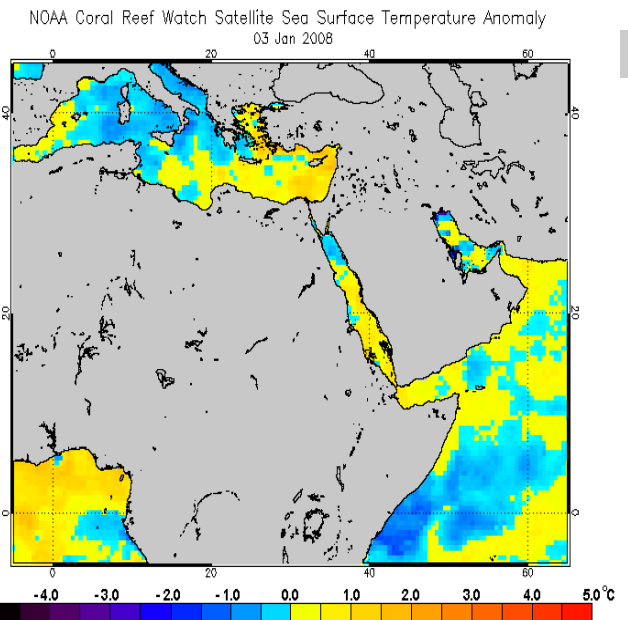

(B)

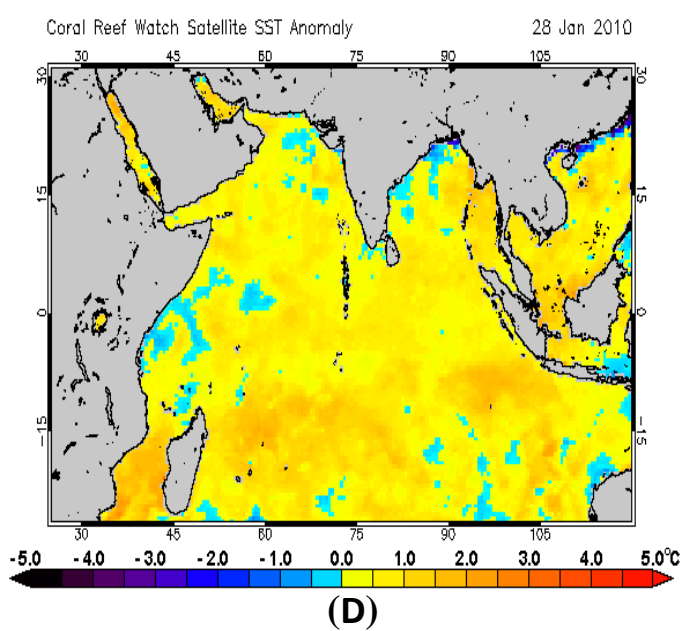

(D)

Fig. 6: Photographs of NOAA coral reef watch satellite Sea Surface Temperature (SST) anomaly. (A) SST anomaly in 2007, (B) SST anomaly in 2008, (C) SST anomaly in 2009, and (D) SST anomaly in 2010. 


\section{ARABIC SUMMARY}

أمراض الثعاب المرجانية فى الغردقة ؛ هل هى نتيجة تأثير الاحتباس الحرارى أم السياحة الجماعية؟

هانى عبد المجيد عبد السلام1 ـ عبد الحميد عبد الرحمن محمد على2 ــ أمين رشدى محمد إسماعيل1 1

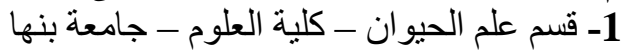

2- المعهد القومي لعلوم البحار و المصايد - فرع العرم السويس

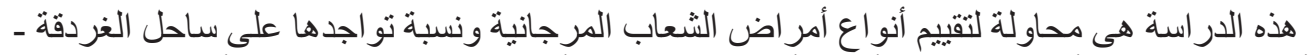

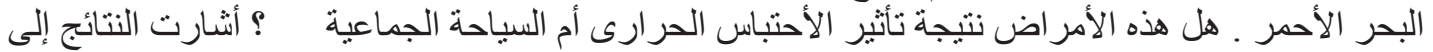

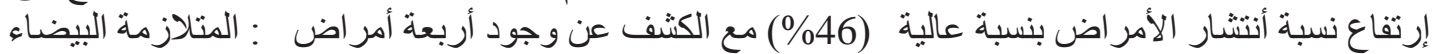

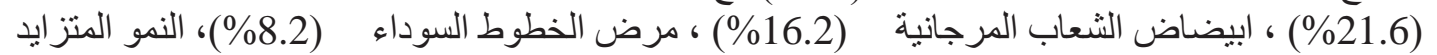

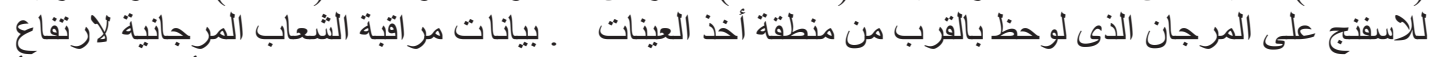

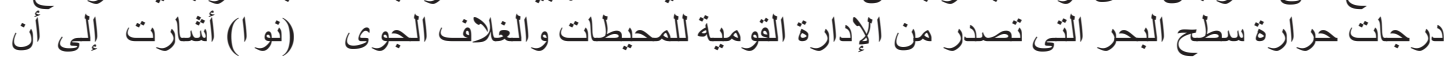

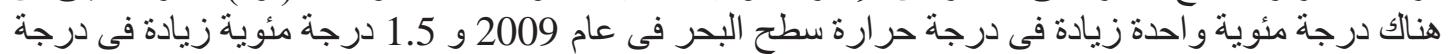

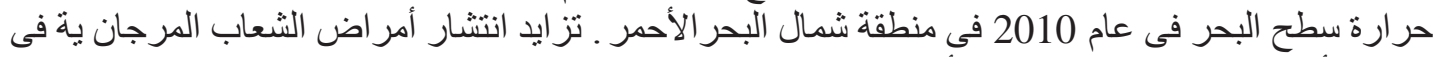

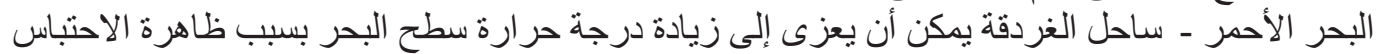

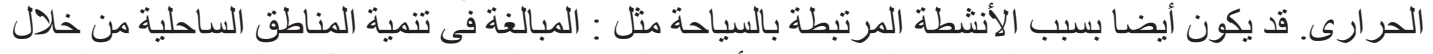

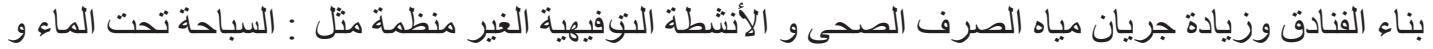
الغوص ـ للحفاظ على هذه الموارد البحرية التى لا تقدر بثمن يتعين علينا أن نتبني مفهوم السياحة البيئية المستدامة بدلا من الأنشطة السياحية العشو ائية. 